\title{
Slogan Publicity and Social Mobilization: As the Research Object of the New China Daily (1937-1938)
}

\author{
Liang Shan ${ }^{1}$
}

\author{
${ }^{I}$ School of Marxism, Northwestern Polytechnical University, Xi'an Shaanxi, China \\ Corresponding author email id:2015202465@mail.nwpu.edu.cn
}

\begin{abstract}
As the official newspaper of the Communist Party of China during the Anti-Japanese War, the New China Daily was responsible for mobilizing the people in the Shensi-Gansu-Ningxia border areas to take an active part in the Anti-Japanese War. As a means of propaganda with strong motivation, slogans appeared on every page of the New China Daily until December 25, 1938 after the luochuan conference. The Communist Party of China used these slogans to carry out effective mobilization of Anti-Japanese War, economy and culture, which promote the national united front policy, implements the comprehensive Anti-Japanese War mobilization, safeguard the people's political participation, safeguard the people's production and living, shape of the Communist Party of China good political image, consolidate the foundation of political legitimacy.
\end{abstract}

Keywords: Anti-Japanese War, The slogan, Social mobilization, New China Daily

\section{Introduction}

The New China Daily was an official newspaper of the central committee of the Communist Party of China and the Shensi-Gansu-Ningxia border region (short name border areas) government during the war of resistance against Japanese aggression. Its original name was the Red China (it was first published in December 1931).According to the New China Daily from January 29, 1937 to December 25, 1938, especially since August 29, 1937, slogans appeared in the left or right margin of every issue and page of the New China Daily, providing a basis for the study of propaganda and political mobilization during the Anti-Japanese War.

These slogans mainly focus on the Anti-Japanese War, and express the support of the border area government for the Anti-Japanese War and its concern for the production and life of the people in the border areas through inspiring and close to life language. As an important way of propaganda, slogans have mobilized and inspired the people in the border areas in their determination to fight the war of resistance and their sense of responsibility to participate in the war of resistance. They have won extensive support for the CPC both ideologically and materially. At the same time, they have established a good image of the CPC in safeguarding national unity and caring about people's livelihood.

\section{Slogans and Social Mobilization in Border Areas during the Anti-Japanese War}

Modern society makes use of newspaper to create public opinion and maintain its legitimacy, which is an effective means of propaganda. In particular, on political issues, no matter in terms of tactics or facts, newspapers and public opinion propagandize politics such as political platform and doctrine.

\subsection{Propaganda of Slogans and Mobilization of the Anti-Japanese War Against the Communist Party of China}

The Anti-Japanese War resistance needs a large amount of financial and material support, and only by mobilizing the whole nation to fight together can we provide a powerful reserve army for the war of resistance. As the official newspaper of the Communist Party of China, the New China Daily actively calls for the national united front with slogans, which shows the determination of the Communist Party of China to defend the nation at a time when the Chinese nation is in peril. In the propaganda of mobilizing the people to join the Anti-Japanese democratic regime, the slogan repeatedly mentioned the establishment of the national united front, mobilizing the border areas, the northwest and the whole country for military and civilian resistance, and at the same time seeking the support of foreign forces for the Anti-Japanese War. The Anti-Japanese War needs a large amount of financial and material support, and only by mobilizing the whole nation to fight together can we provide a powerful reserve army for the war of resistance. The slogans and propaganda of the Communist Party of China fully reflect the policy of the Anti-Japanese national united front. "Consolidate and expand the Anti-Japanese national united front"[1] , "all for national united front, all through the national united front" $[2]$, and other slogans, repeated 20 times, it can be seen in the policy of the Communist Party of China to the 
whole nation of Anti-Japanese War propaganda, the unprecedented support of the fight. The Communist Party of China vigorously supported and mobilized the people in the border areas to participate in the war of resistance in order to increase its human, material and spiritual support. These slogans, with the Anti-Japanese War as the center, carried out the active mobilization of the Anti-Japanese War, formed a wide concern among the public on the issue of the Anti-Japanese War, and finally realized the resultant effect of the mobilization of the Anti-Japanese War.

\subsection{Slogans and the Economic Mobilization of the Border areas by the Communist Party of China}

The Shensi-Gansu-Ningsia border region, as the material supply of the border region and the Anti-Japanese War in the rear of the enemy, is a series of planned and organized activities to transform the border region's economy from peacetime to war time in order to maintain its economic security and improve its economic resilience.[3]During this period, there appeared a large number of slogans to develop production: "mobilize everyone with labor force to go to the production front"[4], "in order to defeat the Japanese aggressors, we must first protect the Anti-Japanese soldiers to eat their fill" [5] $]^{[}$and other slogans. These slogans call on the people in the border areas to actively participate in social production activities and complete the spring and autumn harvest. The development of the production movement has solved the food crisis in the border areas, ensured the livelihood of the army and the people, and provided a solid support for the victory of the Anti-Japanese War and the Liberation War. The party and the government skillfully used the slogan to convey to the people the political tasks such as developing production and paying public grain, and the slogan was easy to understand and spread among the people, thus achieving good economic mobilization.

\subsection{Slogan Publicity and Cultural Mobilization of the Communist Party of China}

Cultural mobilization is a way for the Communist Party of China to let the people understand its mobilization, and it is also a process for the party to get familiar with and serve the people. Strong cultural mobilization can achieve good interaction among the people of the Communist Party of China. During the Anti-Japanese War, the CPC also attached great importance to the Anti-Japanese propaganda and cultural mobilization. At the same time, through cultural mobilization to encourage literacy, eliminate illiteracy, so that the people better understand the Anti-Japanese policy of the Communist Party of China." To spread the new culture of the war of resistance to every corner, and to arm the minds of the masses with it"[6] , "education should be conducted in full time and in full spirit for national defense education"[7].These slogans actively cooperated with the military and civilian Anti-Japanese War, revolutionary literature and art, and mass education in the border areas, so that the people in the border areas could understand the cultural policies of the Communist Party of China from the slogans, and at the same time completed the propaganda task of awakening the people's national consciousness and educating and mobilizing the people to actively resist Japan army.

\section{The Construction Characteristics of the Slogan of New China News}

The slogan of New China Daily spread the theme of the era of Anti-Japanese War and formed the public opinion of active Anti-Japanese War. Slogans serve the people's political, economic and cultural interests and mobilize their political participation.

\subsection{Unity between the Political Task of the War of Resistance and Patriotism}

The slogan of the New China Daily spread the policy of the CPC national united front, mobilized the people in the border areas to take an active part in the Anti-Japanese War, and organized the people to defend in the border areas, the northwest and China. The central task of the New China Daily is to form public opinion in favor of unity and resistance." The army and the people unite to drive the Japanese bandits out of China"[8], "mobilize and arm the whole Chinese people to help the government and the army in the war of resistance"[9] The slogan propaganda with the Anti-Japanese War as the center provided the people in the border areas with the political idea of participating in the Anti-Japanese War, made the people in the border areas support the Anti-Japanese War, encouraged them to participate in the Anti-Japanese War in their daily life, and educated them to defend their own nation and country ideologically. As a favorable propaganda weapon, slogans spread the policies of the CPC national united front, inculcated some new ideologies and moral concepts, national and national consciousness, policies and goals of the CPC, and aroused people's enthusiasm for participating in the Anti-Japanese War.

\subsection{The Combination of Propaganda and Agitation with the Needs of the Public}

The propaganda slogan appeared in the New China Daily has the obvious propaganda drumbeat. This propaganda focuses on people's needs for survival, security, belonging, respect and self-satisfaction" Everything that people fight for, it's all about their interests."[10]. Slogan combines the goal of the public with the goal of slogan publicity, so as to serve the goal of publicity." The slogan spread in the border areas has mobilized the people in the border areas to participate in the Anti-Japanese War and the 
management of the border area government, so that the people in the border areas have the sense of achievement of being their own masters, thus identifying with the rule of the border area government and ensuring the people in the border areas to identify with the border area government. To safeguard the distribution of agricultural loans in the hands of the labouring masses and their use in agricultural production"[11] and "Resolutely protect the people in the border areas from the political, economic, cultural and cultural interests that have been improved."[12] These slogans publicized the tasks of the Anti-Japanese War era and mobilized the people in the border areas emotionally and materially to participate in the war. Signs to make people know the spread of the Communist Party of China attaches great importance to the public interest demand, put the interests of the people in the primacy of the party, let people from psychological love the party, understand the people and the interests of the party is consistent, positive to the front line to take part in the Anti-Japanese War, participate in the rear of the production movement, provide the manpower and material resources support for the war of resistance.

\subsection{The Production and Life of Political Propaganda}

The slogan spread in the border areas has mobilized the people in the border areas to participate in the Anti-Japanese War and the management of the border area government, so that the people in the border areas have the sense of achievement of being their own masters, thus identifying with the rule of the border area government and ensuring the people in the border areas to identify with the border area government. In the Shensi-Gansu-Ningsia border region, the propaganda and mobilization of the Communist Party of China is aimed at the workers, peasants and soldiers, whose cultural level and understanding ability are limited. Therefore, the content of slogans should be close to the reality of production and life, which is easy for them to understand and accept, and more conducive to the mobilization work." Chinese youth and international youth, hand in hand toward an anti-aggression goal"[13] and" Mobilize all forces for victory in the war of resistance! Support the red army in its fight against the Japanese"[14], etc. These slogans in the New China Daily, which are closely related to production and life, mobilize the people and subtly influence the people in the border areas, so that they can realize that their lives are being disrupted and their daily life will be impacted if they do not actively support the Anti-Japanese War. Through the propaganda slogan which is close to the real life and combined with the Anti-Japanese War, it makes the public more receptive to all the thoughts serving the Anti-Japanese War, and plays a role in educating the public to support the Anti-Japanese War.

\section{Conclusion}

As the official newspaper of the Communist Party of China, the New China Daily carries authoritative slogans. The slogans are passed to the public for political information, and these slogans also become the information channel for the public to know about the Communist Party of China. In the New China Daily, the slogan propaganda centering on the Anti-Japanese War fully mobilized the people in the border areas to participate in the war of resistance and spread the Anti-Japanese national united front policy of China. The Communist Party of China used slogans to publicize all the thoughts serving the Anti-Japanese War and the important border area affairs, so as to make the people aware of the border area affairs, shape the good image of the Communist Party of China respecting the people and encouraging their political participation, and establish the Communist Party of China as a political party representing the interests of the nation and the state ideologically, so as to construct its political legitimacy.

\section{REFERENCES}

[1] New China Daily[N]. First edition,1938-1-5.

[2] New China Daily[N]. Second edition,1938-1-5.

[3] MAO Zedong.(1991) Selected works of MAO zedong (vol. 3) [M]. People's publishing house, Beijing.pp. 891.

[4] New China Daily[N]. Second edition,1938-7-20.

[5] New China Daily[N]. Second edition,1938-6-10.

[6] New China Daily[N]. Fourth edition,1938-8-20.

[7] New China Daily[N]. Second edition,1938-6-20.

[8] New China Daily[N]. Third edition,1938-5-15.

[9] New China Daily[N]. Second edition,1938-1-25.

[10] Bureau of compilation and translation of Marx and Engels' works of the central committee of the communist party of China. (1956).Complete works of Marx and Engels: vol.1. People's publishing house,Beijing. pp. 82.

[11] New China Daily[N]. First edition,1938-5-15.

[12] New China Daily[N]. Third edition,1938-6-20.

[13] New China Daily[N]. Fourth edition,1938-9-15.

[14] New China Daily[N]. Second edition,1938-9-10 